\title{
Chapter 17 \\ The Struggle for Recognition and the Professional Identities of Mathematics Teachers
}

\author{
Clyde B. A. Felix
}

\begin{abstract}
All teachers are perpetually engaged in a struggle for recognition of who they are, what they are, and what they are worth. We know that this affects their professional identities, but not enough about what the effects are. This narrative inquiry explores how a struggle for recognition in a rapidly changing post-apartheid school system affected the professional identities of three South African mathematics teachers. Examined through a set of theoretical lenses consisting of Honneth's levels of recognition; Kelchtermans' components of the retrospective dimension of a professional self; and, Huttunen and Heikkinen's circles of recognition, their stories reveal an ability to cope with a lack of recognition by counterbalancing its negative effects with the positive effects of recognition sourced from experiences elsewhere. Surprisingly, their stories have more in common than their sociocultural differences seem to suggest.
\end{abstract}

Keywords Recognition $\cdot$ Self-confidence $\cdot$ Self-respect $\cdot$ Self-esteem $\cdot$ Personal interpretive framework $\cdot$ Professional identity

\subsection{Background}

Recognition is not a new issue in philosophical debate; yet, it is relatively new in educational research (Fleming \& Finnegan, 2010) where it offers a fresh view of teachers' professional growth (Heikkinen, 2003). While social theorists remain divided in their assessment of the emancipatory potential of recognition (Schaap, 2004); there seems to be consensus amongst them on its usefulness as a theoretical tool in the on-going philosophical debates regarding issues of reconciliation and social justice. Thus, the relative novelty of recognition theory in education is rather conspicuous; especially, since education is all about social justice, and recognition is at the heart of it. After all, "[a] teacher's work is a process of receiving and giving recognition" (Huttunen \& Heikkinen, 2004a, p. 164). It would make sense, therefore, for recognition theory

C. B. A. Felix ( $ه)$

Nelson Mandela University, PO Box 77000, Port Elizabeth 6031, South Africa

e-mail: clyde.felix@mandela.ac.za 
to be applied in educational research; for instance, to explore the close interrelationship between recognition and identity or "personhood" (Ikäheimo, 2002, p. 448) in view of a better understanding of teacher professional identity. It is important to understand how the struggle for recognition affects the professional identities of teachers; especially, in continuously changing contexts such as the current postapartheid South African education system. We know that recognition shapes the sense that teachers have of their own professional identities and that this influences their reactions to change and their performance in the workplace (Scholes \& de González, 2011); moreover, that human life is a struggle to be recognised as somebody who is worth something (Heikkinen, 2003). We do not know enough, however, about the mechanisms of recognition to help people to carry on with their job, to enhance their wellbeing, and to understand how a lack of recognition can result in burnout at work, especially, in teaching and learning communities (Huttunen \& Heikkinen, 2004a). This chapter explores how the professional identities of three South African mathematics teachers are affected by their struggles for recognition in the context of a rapidly changing post-apartheid schooling system. All three of the participating teachers are from the Eastern Cape Province; one of the poorest provinces in the country. The struggle for recognition emerged spontaneously as a theme in their autobiographical narratives as they strove to make sense, not so much of who they are, but of what they are as mathematics teachers, and what they are worth professionally. This theme will be explored here through a novel set of theoretical lenses consisting of a combination of Honneth's (1995) hierarchical levels of recognition; Huttunen and Heikkinen's (2004a) circles of recognition; and, Kelchtermans' (1993) components of the retrospective dimension of a professional self or identity.

\subsection{Theoretical Framework}

It is important to note that key aspects of a teacher's professional identity, such as autonomy and self-realisation, can only be achieved intersubjectively through the recognition gained from significant others (Murphy, 2010; Honneth, 2012); recognition is important in social interaction, and "a crucial element in the formation of a person's identity" (Huttunen \& Heikkinen, 2004b, p. 1). The meaning of recognition is not clear and unequivocal, neither in its everyday or philosophical use, nor in the English or German language (Ikäheimo, 2002). Ikäheimo (2002) and Heikkinen (2003) point out three distinct interpretations of recognition that are common in everyday use: firstly, recognition in the sense of identification; secondly, recognition in the sense of admitting one's mistakes; and thirdly, recognition in the sense of acknowledging and honouring the status of the other. While Ikäheimo (2002) focuses on only the third interpretation, I follow Heikkinen (2003, p. 1) in focussing on the first and third interpretations. The first interpretation is of recognition as a reference to perception and identification, in other words, to "recognise something as something", for instance, to be recognised $a s$ a teacher. The third interpretation is of recognition as a reference to acknowledgement and honouring of the status of the other, in other 
words, to "recognise something as worth something", for instance, to be recognised as a worthy teacher. Noticing the close interrelatedness of these two interpretations, Heikkinen (2003) argued that, "to recognise something as something is half-way towards recognising something as worth something, and vice versa" (p. 2). For the individual, the most basic form of recognition is often to be noticed or seen; the worst kind of humiliation is not to be noticed or seen. The recognition in which we are interested, however, is of the genuine kind, not polite behaviour (etiquette) or fake compliments with the intention to manipulate in a behaviouristic manner (Huttunen \& Heikkinen, 2004a). Recognition has been described as a "vital human need" (Taylor, 1992, p. 26); however, like most other human needs, it does not come without a struggle. The struggle for it goes beyond being noticed or seen; it is a struggle to be recognised, not only as a professional, but also as a worthy professional. For individual autonomy - a type of individual relation-to-self that allows one to be self-confident in one's needs and beliefs, and to value one's capacities- to emerge and flourish, reciprocal, inter-subjective recognition is mandatory (Honneth, 2012). The struggle for professional recognition is also a struggle for gaining membership and for legitimate participation in the activities of professional communities of practice (Heikkinen, 2003; Huttunen \& Heikkinen, 2004a). A teacher's struggle for professional recognition is also a struggle for a professional identity; whether it is only a light struggle, such as in a friendly environment amongst family, friends and encouraging colleagues, or a heavy struggle resembling a "bloody battle" among adversaries (Huttunen \& Heikkinen, 2004b, p. 3).

\subsubsection{Honneth's Three Levels of Recognition}

At the heart of Honneth's (1995) theory is the premise that "practical identityformation presupposes inter-subjective recognition" (p. 92) at three hierarchical levels of social integration: emotional bonding (love); the granting of rights (legality); and a shared orientation to values (solidarity). The individual gradually progresses form the first level on to higher levels. The first and most basic of Honneth's (1995) three hierarchical levels of recognition is the establishment of self-confidence ( Selbsvertrauen); usually, during childhood and in primary relationships of love, friendship and care with significant others. At this level it is key for one's needs to be expressed without fear of rejection and abandonment; for one's existence as an individual in social interaction to be recognised; for one's right to exist to be reaffirmed; and for one's uniqueness as an individual (Who am I?) to be recognised. Through the experience of such special relationships with significant others, one becomes aware of one's own uniqueness and special characteristics and develops a positive image of one's abilities (Fleming \& Finnegan, 2010). This is a precondition for further development; without self-confidence the attainment of the more advanced levels of self-relations, namely self-respect and self-esteem, would be impeded (Honneth, 1995; Huttunen, 2001; Huttunen \& Heikkinen, 2004a; Murphy, 2010). Through the experience of unconditional love, one develops the ability to love one-self and others 
(Fleming \& Finnegan, 2010). Moreover, through such early relations with one's parents one develops a basic level of trust (Huttunen \& Heikkinen, 2004a) and the ability to trust others, which is an important aspect of interpersonal relations. Although it is fundamental for children's development, the first level of recognition is important for everyone, regardless of their age. The experience of love and care, according to Huttunen and Heikkinen (2004a), is "a precondition for the development of an individual's identity and morality (Sittlichkeit)" (p. 167).

The second of Honneth's (1995) levels of recognition is the establishment of selfrespect (Selbstachtung) which comes with the recognition of one's professional self by civil society as a legally mature person with legal rights (What am I?). This is linked to the attainment of a qualification which allows one to practice as a professional with legal and moral autonomy and "with equal rights, in the institutional order as a full-fletched member of a community" (Honneth, 1995, p. 133). This answers in the professional "need to be recognised as a free and autonomous citizen ... as a mature person with mind of her own and right to make legal contracts" (Heikkinen, 2003, p. 1) and is usually articulated in a teacher's diploma that gives the graduate the right to practice as a teacher in certain societies. At this level, the individual is trusted with the responsibility for his or her own actions; as opposed to a paternalising attitude which denies the individual freedom of will, autonomy and the ability to work independently (Huttunen, 2001; Huttunen \& Heikkinen, 2004a).

The third and highest of Honneth's (1995) levels of recognition, self-esteem (Selbstschätzung), refers to recognition and acknowledgement of our abilities and accomplishments at work (What am I worth?), for instance, when mentors and colleagues recognise one's successes at work (Heikkinen, 2003). According to Huttunen (2001), individual freedom of will can only be expressed through self-directed, autonomous work, and it is only when that freedom of will is directed towards common good that respect and recognition of the community is earned: "[T]he individual really becomes recognised as a person who has something to give to the community. The reciprocal recognition of each other's work creates a strong feeling of solidarity in the community. In such communities individuals are strongly motivated and enjoy their work" (p. 426). Such a shared orientation to values fosters solidarity.

Honneth's (1995) three levels of recognition are summarised in Table 17.1. This table would not be complete without showing the forms of disrespect associated with each of these levels of recognition and briefly explaining how these relate to the teachers' struggles for recognition and professional identity. Thus, the table has been adapted accordingly, followed by an explanation of the forms of disrespect associated with each of the levels of recognition.

At the first level, the disrespect is an assault on an individual's physical integrity. Extreme forms of this could be physical abuse and even rape. The denial of physical integrity is likely to result in permanent psychological damage, which could interfere with the development of practical self-relations (Huttunen, 2001; Huttunen \& Heikkinen, 2004a) and interpersonal relations.

At the second level, the disrespect is the denial of an individual's social integrity, usually through the denial of rights and social exclusion. The individual is denied freedom of will, not considered a subject of his or her own actions, but rather as an 
17 The Struggle for Recognition and the Professional Identities ...

Table 17.1 Honneth's (1995) levels of recognition and associated forms of disrespect

\begin{tabular}{l|l|l|l}
\hline Levels of recognition & First & Second & Third \\
\hline Mode of recognition & Emotional support & Cognitive respect & Social esteem \\
\hline Dimension of personality & Needs and emotions & $\begin{array}{l}\text { Moral } \\
\text { responsibility }\end{array}$ & Traits and abilities \\
\hline Forms of recognition & $\begin{array}{l}\text { Primary } \\
\text { relationships } \\
\text { (love, friendship) }\end{array}$ & $\begin{array}{l}\text { Legal relations } \\
\text { (rights) }\end{array}$ & $\begin{array}{l}\text { Community of } \\
\text { value (solidarity) }\end{array}$ \\
\hline Developmental potential & - & $\begin{array}{l}\text { Generalization, } \\
\text { de-formalization }\end{array}$ & $\begin{array}{l}\text { Individualization, } \\
\text { equalization }\end{array}$ \\
\hline Practical relation-to-self & $\begin{array}{l}\text { Basic } \\
\text { self-confidence }\end{array}$ & Self-respect & Self-esteem \\
\hline Forms of disrespect & Abuse and rape & $\begin{array}{l}\text { Denial of rights, } \\
\text { exclusion }\end{array}$ & Denigration, insult \\
\hline $\begin{array}{l}\text { Threatened component of } \\
\text { personality }\end{array}$ & Physical integrity & Social integrity & Honour, dignity \\
\hline
\end{tabular}

Note Adapted from Honneth (1995, p. 129)

object that causally reacts to stimuli, with the result that the development of moral responsibility is stunted (Huttunen, 2001; Huttunen \& Heikkinen, 2004a).

At the third level, the disrespect is the denigration and insult of an individual's honour and dignity, usually by withholding recognition for work worthy of recognition and giving feedback only when mistakes have been made. Such denial of recognition for good work and continuous negative feedback will inhibit the development of the individual's self-esteem. In worst case scenarios, for instance, when disrespect turns into "mudslinging", usually by people who suffer from weak self-esteem themselves, the struggle for recognition could turn into a vicious circle which may have severely detrimental effects on the development of interpersonal relations (Huttunen, 2001; Huttunen \& Heikkinen, 2004a).

\subsubsection{Huttunen and Heikkinen's Circles of Recognition}

Noting the importance of recognition in social interaction and identity formation, Huttunen and Heikkinen (2004b) distinguished between positive circles of recognition, which create feelings of solidarity and job satisfaction, and negative circles of recognition, which have erosive effects on working communities, like lack of solidarity and diminished motivation for teamwork. Heikkinen (2003, p. 2) explained that while positive circles of recognition refer to "reciprocal giving and getting of recognition [which] leads to a sense of solidarity"; negative circles of recognition, in contrast, refer to "lack of reciprocal recognition [which] may lead to an atmosphere of indifference and disregard". A summary of the main differences between the pos- 
Table 17.2 Differences between Huttunen and Heikkinen's positive and negative circles of recognition

\begin{tabular}{l|l}
\hline Positive circle of recognition & Negative circle of recognition \\
\hline $\begin{array}{l}\text { Developed through reciprocal recognition } \\
\text { through which persons respect each other as } \\
\text { persons and appreciate each other's skills and } \\
\text { abilities }\end{array}$ & Persons downplay each other \\
\hline $\begin{array}{l}\text { Creates a feeling of solidarity and satisfaction } \\
\text { with one's job. Individuals feel that they are } \\
\begin{array}{l}\text { important and respected members of the } \\
\text { community }\end{array}\end{array}$ & $\begin{array}{l}\text { Erodes the working community. The lack of } \\
\text { solidarity diminishes the individuals' } \\
\text { motivation for teamwork and thus affects the } \\
\text { results of work; often resulting in burnout }\end{array}$ \\
\hline
\end{tabular}

Note Adapted from Huttunen \& Heikkinen (2004a, 2004b)

itive and negative circles of recognition (Huttunen \& Heikkinen, 2004a) is offered in Table 17.2.

There are several reasons why it is important to know the mechanisms behind positive and negative cycles of recognition; for instance: to promote a supportive atmosphere in teacher education (Heikkinen, 2003); to enhance the well-being of teaching staff and assist them to cope with their job and avoid burnout; and to assist teachers and mentors to become better at what they do (Huttunen \& Heikkinen, 2004b). Both recognition and the professional identities of teachers depend on interpersonal subjectivity and therein lies the potential of recognition to affect professional identities. It makes theoretical sense, therefore, to construe the circles of recognition as a conceptual bridge between the teachers' struggle for recognition on the one hand and their quest for a professional identity on the other. Interestingly, both teacher professional development and the struggle for recognition are life-long learning processes (Kelchtermans, 2004).

\subsubsection{Kelchtermans' Components of a Personal Self}

The personal interpretive framework proposed by Kelchtermans (1993) is useful because it allows for a narrative understanding of teacher professional identity. This framework shares some characteristics with narratives; two of these are evident in Vanassche and Kelchtermans' (2016) description of it as: "always temporary", and as "a lens through which they [teachers] perceive their job situations, give meaning to, and act in them" (p. 2). An individual teacher's professional self, however, is more than an idiosyncratic construction; the self also is a product of that individual's interaction with the environment. Anspal et al. (2012) explained that the self is shaped by writing or talking about it, and that teacher professional identity development puts the self in a specific context, for instance, the school environment.

Kelchtermans (1993) acknowledged the interwoven nature of past, present, and future in biographical perspectives in his personal interpretive framework and split 


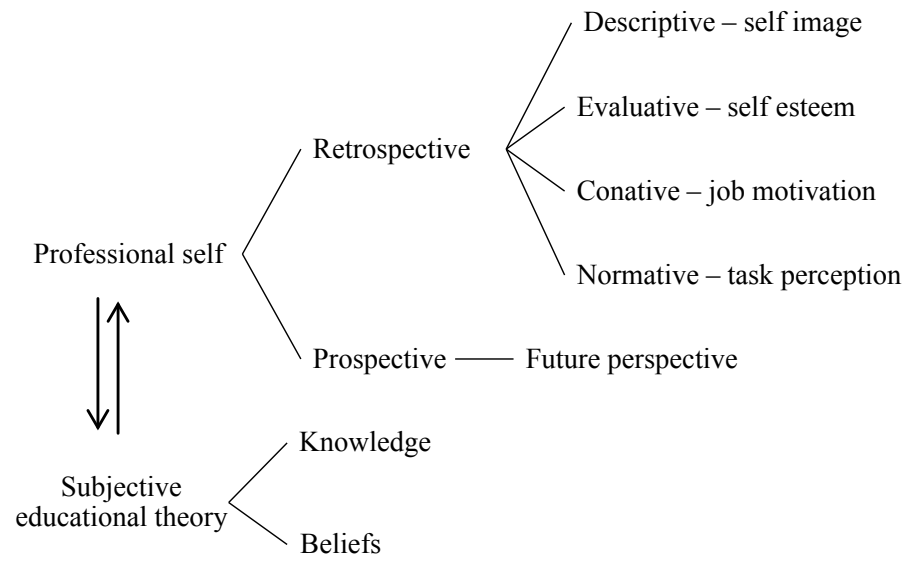

Fig. 17.1 Kelchtermans' components of the personal interpretive framework. Note Adapted from Kelchtermans (1993, p. 448)

the professional self (identity) into a retrospective and a prospective dimension. The teachers' notion of their professional self (identity) and their subjective educational theory, based on their knowledge and beliefs, are in reality intertwined and tightly woven into their personal interpretive framework: this is acknowledged in Fig. 17.1 with a double arrow between professional self and subjective educational theory.

The retrospective dimension deals with conceptions of the professional self as the individual looks back from the present into the past and consist of four components (Kelchtermans, 1993, p. 449):

- Descriptive (Self-image) component: the global characterisation of oneself as encapsulated in one's self descriptive statements. In other words, how a teacher describes him- or herself as a teacher. Often descriptions are formulated in terms of general principles that govern teachers' professional behaviour; but also by referring to the way teachers think they are perceived by others.

- Evaluative (Self-esteem) component: the evaluation of oneself as a teacher. Often the learners are seen as the most important determinants of a teacher's self-esteem. Indicators include the learners' school results, but also the quality of the personal relationship with the teacher. Other important indicators include, for example, comparison with other teachers.

- Conative (Job motivation) component: the motives for choosing the job, staying in it, or leaving it. In other words, the things about their job that motivates or demotivates teachers.

- Normative (Task perception) component: the way teachers conceptualise their job. This is crucial as a norm in evaluating their professional behaviour and may include narratives of the quality of their relationship with their learners, and/or their striving for professional (didactical) competence. 
The prospective dimension (future perspective) deals with teachers' expectations for future developments of their job situation and how they feel about this. The subjective educational theory is described as: "the personal system of knowledge and beliefs teachers use while performing their job" (Kelchtermans, 1993, p. 450). This might be the result of career experiences that a teacher has had and how these are, more or less reflectively, integrated into practice. As Kelchtermans (1993) explained: "In terms of the conceptual framework one could say that the subjective educational theory contains the knowledge and beliefs that are used by the teacher to implement the personal-professional programme implied in the task perception" (p. 450). The content of a subjective educational theory can only be reconstructed in a fragmented way:

One never gets the whole picture. Not only because it changes with new experiences, but also because the teacher per definition has no conscious access to his or her entire 'theory'. Further the reconstruction is bounded by the reflective capacity of the teacher and by the degree he or she is willing to share his or her ideals with someone else. (Kelchtermans, 1993, p. 451)

This study draws on the four components of the retrospective dimension of Kelchtermans' (1993) personal interpretive framework which comprehensively cover the aspects of a teacher professional identity which could be influenced by struggles for professional recognition in the workplace.

\subsection{Methodology}

The struggle for professional recognition in the workplace emerged as a salient theme in the autobiographical narratives of mathematics teachers who participated in a narrative inquiry (Clandinin \& Connelly, 2000; Connelly \& Clandinin, 1990; Daiute \& Lightfoot, 2004; Kramp, 2004) into the narrative shaping of their professional identities. Their narratives were collected over a period of eighteen to twenty four months. Seven experienced mathematics teachers participated in the original study; they were purposively selected from government funded schools in the Eastern Cape Province of South Africa; and their teaching experience and sociocultural backgrounds were taken into account during the selection process. The sample included only participants with first-hand experience of the continuously changing context of the post-apartheid South African education system over the past twenty years and who are representative of the demographic profile and cultural diversity of teachers in government funded schools the Eastern Cape Province of South Africa. The focus of this chapter is on the struggles for recognition distilled from the autobiographical narratives of three of the original seven participants (P1, P2 and P3) whose demographic profiles are summarised in Table 17.3.

During the semi-structured interviews participants were asked to reflect, in as much detail as possible, on the high points, low (nadir) points, and turning points in their professional teaching careers. These interviews were audio-recorded, transcribed in verbatim, and later reviewed by the teachers using member checking to 
Table 17.3 Demographic profile of the participants

\begin{tabular}{l|l|l|l|l|l|l}
\hline & $\begin{array}{l}\text { Age (in } \\
\text { years) }\end{array}$ & $\begin{array}{l}\text { Ethnicity } \\
\text { and } \\
\text { gender }\end{array}$ & Home language & $\begin{array}{l}\text { Teaching } \\
\text { experi- } \\
\text { ence (in } \\
\text { years) }\end{array}$ & $\begin{array}{l}\text { School } \\
\text { district }\end{array}$ & $\begin{array}{l}\text { School } \\
\text { type }\end{array}$ \\
\hline P1 & 50 & $\begin{array}{l}\text { Black } \\
\text { male }\end{array}$ & isiXhosa & 23 & $\begin{array}{l}\text { Port } \\
\text { Elizabeth }\end{array}$ & $\begin{array}{l}\text { Urban, } \\
\text { township }\end{array}$ \\
\hline P2 & 48 & $\begin{array}{l}\text { 'Coloured' } \\
\text { female }\end{array}$ & Afrikaans/English & 26 & $\begin{array}{l}\text { Port } \\
\text { Elizabeth }\end{array}$ & $\begin{array}{l}\text { Urban, } \\
\text { township }\end{array}$ \\
\hline P3 & 56 & $\begin{array}{l}\text { White } \\
\text { male }\end{array}$ & English & 32 & $\begin{array}{l}\text { Port } \\
\text { Elizabeth }\end{array}$ & $\begin{array}{l}\text { Urban, } \\
\text { ex-Model } \\
\text { C }\end{array}$ \\
\hline
\end{tabular}

confirm the validity and credibility of the transcripts (Creswell \& Miller, 2000). Because English is not the mother tongue of all of the participants, it was sometimes necessary to infer meaning from what they have said; for instance, inferring from Participant 1's (P1's) remark, "this teacher is not the one who is driving what you are driving" ( $\mathrm{P} 1 ; 1$ st interview), the meaning that the other teacher is not cooperating because they lack a shared orientation to values or solidarity. Where such inferences were necessary, the researcher's interpretation was verified using member checking (Guba, 1981; Creswell \& Miller, 2000). Consistency in responses across interviews of a participant was regarded as evidence of the occurrence of events as narrated (Caruso, 2013). During a narrative analysis, there is need for on-going conceptualisation while collecting data (Vandenberghe, 1996); hence, a blend of horizontal or cross-case analysis (Miles \& Huberman, 1994) and constant comparative analysis (Glaser \& Strauss, 1967) was used to uncover common themes or patterns. Participants were interviewed at least four times each over a period of roughly eighteen to twenty four months, making it possible to fill gaps in their storylines, clarify uncertainties and check inferences.

\subsection{Results and Discussion}

While the results of this study cannot be generalised, the negative effects of a lack of professional recognition, or disrespect, in the workplace on the three participants' self-respect (What am I?) and self-esteem (What am I worth?) are evident in their autobiographical narratives. The narrative data shows that the disrespect is either at Honneth's (1995) second level, self-respect, or at the third level, self-esteem, and that for all participants the first level, self-confidence, remains intact. There is also evidence in the narrative data that the negative effects of such disrespect give rise to negative circles of recognition, characterised by mutual downplaying of each other, lack of solidarity and diminished motivation for teamwork; all of these have negative implications for the professional identities of the participants. There is also 
strong evidence, however, that the participants have developed strategies to cope with the negative effects of such lack of recognition or disrespect; for instance, they would draw on narratives of positive circles of recognition, interspersed with feelings of reciprocal recognition, solidarity, and job satisfaction, to minimise the effects of negative circles of recognition on their professional identities. The narrative data also shows that the source of positive circles of recognition seems to be the participants' strong sense of self-confidence (Who am I?); most likely, because all of them had been privy to primary relationships of love, friendship, and care with significant others. Thus, the narrative data underlines the importance of Honneth's (1995) first level of recognition, self-confidence, as a precondition for the development of identity and morality (Huttunen \& Heikkinen, 2004a), and for enhancing the survival options of those on the receiving end of lack of recognition, or disrespect, on the other levels. The following discussion will focus on three of the selected participants' narratives of their experiences of lack of recognition, or disrespect, in the workplace: exploring the effects on their professional identities, and how they managed to cope.

\section{The Story of Participant 1}

In this story, Participant 1 (P1) recounts the struggle for recognition of his worth as a mathematics teacher in a context where his colleagues are denying his contributions to the learners' good results and turn down his genuine offers to share some of his expertise with them. This happened at a school in a historically 'Black' township of Port Elizabeth about a year after P1, a fully qualified mathematics teacher with a fair amount of experience, had accepted a teaching post there.

[Y]ou do your utmost best to assist a particular teacher now in ensuring that the learners are doing their best and what you are trying to put in is not appreciated. That, to me, becomes my low point. You will find that learners are keen to work, but this teacher is not the one who is driving what you are driving or you are not in the same level. That, to me, it's one of the key things that kills me! And it makes me to be demotivated, because at the end of the day you try to help, but this help is not appreciated even if those learners move to a higher level. That is [what] I will consider as a low point [...] We look at the results [matric pass rates] of the school, when I got into this particular school; I worked with learners though I came in September 2001. They got 89\%. The following year I worked with those learners in the midst of educators not trying to assist me because I came and the results were high. And they said: 'No, it's not your results!' But I said: 'All right, I'm going to prove a point!' The following year I worked with the learners. After school, we were staying; we were working, both with maths and physical science; because those were my specialities. Working with those learners then proved fruitful. We got $99 \%$ so only one learner failed; it's the one that was not attending the school! So that to me, is my, my experience, where you are not needed and then you pull yourself away. Where learners are going all out you tend to have much success. I do have some resistance, or there is some resistance from time to time from the educators as you are assisting the learners. It's like you are intimidating, but it should not be! We are assisting learners and helping the learners. So if a situation where you feel that you are uncomfortable. That to me, I feel, is not the way you should be because we are helping the learners here and learners must do their best. You must let go of your selfish egos because you are thinking that I am intimidating whereas I just want to assist the learners. So to me, it is one of the things. [...] It's as if, if you give assistance, the accolades will go to you. Which is not like that! Teachers sometimes they said: 'All right, I'm going to do $a$ and $b$ and $c$, and see what he will do!' So you have those ones that wants to pull down. We call it a 'pull-down-syndrome'. But at the end it's at the detrimental the child. So there were 
some incidents where teachers... they do not welcome the external assistance. Actually, it's a really, really sad case $(\mathrm{P} 1 ; 1$ st interview).

In this story, P1's struggle for recognition is against a form of disrespect linked to Honneth's (1995) third level of recognition, self-esteem, and described as a denigration and insult to an individual's honour and dignity. P1 regards it as a "low point" in his career. In South Africa, good pass rates or "results" are highly valued, especially in the final school-leaving or "matric" examination, and are frequently used as a measure of a teacher's worth; linking the individual's self-esteem with learner performance. When P1's colleagues denied his contributions to the school's good pass rates in mathematics and science, "No, it's not your results!", and attempted to undermine him, "All right, I'm going to do $a$ and $b$ and c, and see what he will $d o$ !", he experienced their actions as an insult and denigration of his worth as a teacher and self-esteem. He refers to this kind of deliberate disrespect as a "pulldown-syndrome". This story is about P1's struggle for recognition of his worth as a competent mathematics and science teacher: "maths and physical science... those were my specialities". It is not surprising that he describes this experience as a "low point" in his teaching career. The effects of negative circles of recognition (Heikkinen, 2003; Huttunen \& Heikkinen, 2004a, 2004b) are evident in their downplaying of each other, "All right, I'm going to do a and b and c, and see what he will do"; their lack of shared orientation to values or solidarity, "this teacher is not the one who is driving what you are driving"; and, diminished motivation for teamwork, "where you are not needed and then you pull yourself away". Negative circles of recognition often lead to a demoralising atmosphere, which can result in exhaustion and burnout (Heikkinen, 2003). This has affected P1's motivation for teamwork and the conative (job motivation) component of his professional identity. He described the experience as "one of the key things that kills me! And it makes me to be demotivated". Usually, the resulting atmosphere of indifference and disregard is enough to make most teachers consider leaving the profession and, in severe cases, can even cause burnout (Huttunen \& Heikkinen, 2004a). Apparently, P1 has managed to survive by counterbalancing the effects of negative circles of recognition with the effects of positive circles of recognition drawn from other experiences linked to levels lower down on Honneth's (1995) hierarchical scale of recognition. He has two such stories in his narrative repertoire. The first is a story of the role that his family had played in the development of his self-confidence.

Because my father divorced my mother at an early age, I was very, very young and that in itself made me to have certain vows that I have with me. My mother was able to take us... we were two from my mother... was able to take us from... I don't know whether you have seen a dog taking its puppy from one place to another? Though she was a domestic worker she made sure that at least there is something for us for our education as well and that to me... even in difficult times she will make sure that we have at least money to go and study. I studied at different universities and before I could do that, I had to go back and work myself before I can again go. So it was her influence that has made where I am or what I have become, meaning the support she has given me whilst growing up in her father's house. That's also one of the great things that I've learnt as a father-figure in the house. I've learnt it from grandfather-that is [name of grandfather]. They usually called him [nick-name of grandfather] and even now I have a shop that is called [name of shop] because of thinking 
about him and honouring him for what he has done in my life. My family, the ones, they have been there for me, meaning they did not trouble me or even having problems with me when I say I must go and study. Study was number one because they know that I was the leader in the study groups $(\mathrm{P} 1 ; 2$ nd interview).

This story of how the support, love and care of his significant others (his mother, grandfather, wife and two children) have laid the foundations for the establishment of self-confidence, is in line with Honneth's (1995) first level of recognition, that of emotional bonding (love). His mother made sure of that her children could express themselves without fear of abandonment. Despite being divorced with no fixed address and a low paying job, as a domestic servant, she nevertheless took care of her children's needs: "I don't know whether you have seen a dog taking its puppy from one place to another?" They knew that they could count on their mother to make provisions for his studies, "even in difficult times she will make sure that we have at least money to go and study". This enabled P1 to develop self-confidence, which he acknowledges as follows: "So it was her influence that has made where I am or what I have become, meaning the support she has given me". The rest of his family was also supportive. His grandfather, acting as a father figure, provided a stable home; and his wife and children understood and supported his studies. A positive circle of recognition (Heikkinen, 2003; Huttunen \& Heikkinen, 2004a, 2004b) is evident in the reciprocal recognition, for instance, "they have been there for me" and in return, "honouring him [grandfather] for what he has done in my life". Also in the feeling of solidarity and satisfaction of knowing that they supported him, "they have been there for me [...] because they've seen how involved I was in my studies". This made him aware of his own uniqueness and special characteristics and helped him to develop a positive image of his abilities (Fleming \& Finnegan, 2010). This also gave him the self-confidence to complete his studies and to become a qualified mathematics teacher; paving the way for recognition at Honneth's (1995) second level of recognition, granting of rights (legality), which usually culminates in self-respect for the recognised. The fact that $\mathrm{P} 1$ is a well-qualified mathematics teacher with ample selfconfidence, elevates his struggle for recognition beyond Honneth's (1995) second level, that of self-respect (What am I?), to the next level, that of self-esteem (What am I worth?). This is how the effects of the positive circle of recognition helps P1 to counterbalance the effects of the negative circle of recognition. The second story is of the early recognition of P1's mathematical and teaching proficiency by his high school teachers, and later by his college lecturers. This story, like the first one, is also in line with Honneth's (1995) first level of recognition. Although the experience can hardly be described as an act of emotional bonding or a caring relationship of love with significant others in the traditional sense, it still contributed to the development of P1's self-confidence.

We were not having enough educators, so I was taken to teach the lower classes. As it was moving up from standard six [Grade 8], standard seven, standard eight [...] So, that then became, what I call my passion for maths [...] I can start again from my high school. The way educators trusted me in ensuring that I'm helping those learners... And those learners actually were doing their best! And I found that it is exciting. But as I moved on, I found that as I moved maybe to a college, I found that, that college lecturer used me again within 
the class to help. As I moved the university, I found that I've been utilised again. So that to me, ugh... has really made me change the way I do things, and the excitement that is there is still there because I've been utilized in one way or the other. I don't know why they are not using others but they will use me all the time. So I love that. Ugh, I love to share. I love to make sure other people understand maths (P1; 1st interview).

Qualified mathematics teachers are scarce in the Eastern Cape Province. When no qualified teachers available, learners often, spontaneously, end up teaching each other. In P1's story this was not a spontaneous process, "I was taken to teach the lower classes". This process, sanctioned by the teachers at the school, is perhaps why he construes this experience as recognition of his mathematical and teaching proficiency: "The way educators trusted me in ensuring that I'm helping those learners... And those learners actually were doing their best!". This and other similar experiences are construed as recognition of his uniqueness as an individual with special characteristics, "I don't know why they are not using others but they will use me all the time", and contributes to a positive image of his abilities, "So I love that". The effects of positive circles of recognition are evident in the reciprocal recognition in the respect shown for P1's skills and abilities, "educators trusted me"; and, in feelings of solidarity and job satisfaction, "the excitement that is there is still there because I've been utilized in one way or the other"; and also, "I don't know why they are not using others but they will use me all the time". In P1's own view, this is evidence of these professionals recognising him as a member of their professional community of mathematics teachers. Such experiences of professional inclusion contributes to the formation of a professional identity (Castañeda, 2014). In P1's story, all four of Kelchtermans' (1993) components of a retrospective self are affected; for instance, the normative component, "that to me... has really made me change the way I do things"; the descriptive component, "I love to share. I love to make sure other people understand maths"; the evaluative component, "those learners actually were doing their best!" and "they will use me all the time"; and lastly, the conative component, "the excitement that is there is still there". All of these are positive outcomes for his professional identity brought about by the experience of a positive circle of recognition. It could be argued that asking P1 to take those classes was an act of necessity and desperation because there were no qualified mathematics teachers; and, that it is common practice to use senior students as student assistants in college and university; therefore, these were not necessarily instances of recognition. However, from a narrative perspective, the way in which $\mathrm{P} 1$ makes sense of these experiences is important; and, there is strong evidence that he sees these as instances of recognition: "I don't know why they are not using others but they will use me all the time" (P1, 1st interview). His argument makes sense, because they could have used others instead. The recognition that $\mathrm{P} 1$ received from his teachers and lecturers made him aware of his passion for teaching mathematics, gave him self-confidence, and shaped him into who he is as a mathematics teacher. As shown here, this would be a valuable source in later struggles for more advanced levels of recognition. Notably, in the struggle for self-esteem when the actions of his colleagues called into question his worth as a mathematics teacher. The ability to counterbalance the effects negative circles of recognition with the effects of positive circles of recognition, drawn from beyond 
the immediate contexts of his struggles, have enabled P1 to survive the disrespect of his colleagues in the constant struggle for recognition.

\section{The Story of Participant 2}

In this story, Participant $2(\mathrm{P} 2)$ recounted her struggles to maintain her self-respect in a context where colleagues downplayed her qualifications and refused to work with her. All of this happened at a school in a historically 'Coloured' township of Port Elizabeth where she had started her teaching career at least twenty-six years before the interview. In this township school, like in P1's school, there have been very little post-apartheid changes, except for the many curriculum changes. There has been no change in the demographic profile of the staff, so all of the teachers are from broadly similar sociocultural backgrounds.

[L]ow points are when you don't get the cooperation of, firstly, your students, and then another major thing is when [...] you don't get cooperation with your colleagues. When you work with somebody you're supposed to work in a group, and, you just find you are fighting a losing battle. This person is just going ahead and doing his or her thing... You know. And for me, at the end of the day, it's not about me [...] but when your colleagues work against you, that is very demotivating [...] You are three or four teaching Grade 8 Maths, and I'm working here, you're working there... and he's working over there... And each one is just doing his own thing. That is very, that's low... That's the low point for me. But I've had to learn to work around that. I've had to learn to make, make it work, because even though you try hard to get your colleagues to work together, you just don't get the necessary cooperation, but at the end of the day, I've had to learn to work around it [...] When colleagues are better qualified than you are, they have this attitude; you cannot come and tell them! I've had that experience [...] when I tried to tell the person 'You mustn't do it like this, you must do it like that' and gave the things that I had, the person said to me that they don't like the way I speak to them, and they can't understand, because they are academically better qualified than I am [...] I can take it, I can handle it, but I don't want to hear that all the time. For me, it's not about qualifications. I mean I'm a what? I am a [name of college] teacher and I went and did my, the ACE [Advanced Certificate in Education] Maths Literacy Course and, I'm happy! I don't need to go and get Masters and whatever... I'm content. I'm not searching [...] For me at the end of the day, if my children fare well, I'm good and if they don't, what can I do about it, it's not about me, it's about the child at the end of the day [...] It doesn't matter what qualifications I've got, we are here at the end of the day because of the children [...] a lot of people will tell you that they compete, but experience counts... but for me that's not important. Fine, I'm teaching 20 odd years and you learn as you go along and you find out, today it doesn't work, and you had to try something different the next day, but when you have colleagues that don't cooperate... and you've tried, you've tried to speak, you've tried to sort it out in the office, and the Principal has tried his part, but the person is just not giving his cooperation, what more can you do? You know what I'm saying? So, that's a major problem and I'm not the kind of person... who can speak to other people... I'm not... I'm a quiet, I see myself as quiet, as a shy person, but when I'm in my classroom, that's where I perform, where I enjoy myself in front of the children (P2; 1st interview).

The disrespect shown in this story is social exclusion, "even though you try hard to get your colleagues to work together, you just don't get the necessary cooperation"; and, the denial of legal rights, "When colleagues are better qualified than you are, they have this attitude; you cannot come and tell them!" Linked to Honneth's (1995) second level, self-respect, the downplaying of P2's qualifications is a form of denigration and insult; and, the questioning of her legal authority and moral autonomy to speak to them on equal terms as a fellow professional teacher is a form of 
denial of rights and exclusion. Both are assaults on her self-esteem and self-respect as a teacher. Her question "I mean I'm a what?" implies that her struggle is mainly about maintaining self-respect. She knows that she is suitably qualified and is quite content with her qualifications, "For me, it's not about qualifications [...] I'm happy! I don't need to go and get Masters and whatever". The effects of negative circles of recognition (Heikkinen, 2003; Huttunen \& Heikkinen, 2004a, 2004b) are evident in the downplaying of each other, "they have this attitude; you cannot come and tell them! [...] because they are academically better qualified"; the lack of solidarity, "your colleagues work against you"; and, diminished motivation for teamwork, "you're supposed to work in a group, and, you just find you are fighting a losing battle". It seems that P2 is quite resolute in maintaining her self-respect; not all of the components of her professional self or identity were affected, even though the experience has prompted her to reflect on them all. Her rhetorical question "I mean I'm a what?" can be interpreted either as a reflection on her self-image as a teacher, linked to the descriptive component, or, as a reflection on her task as a teacher, linked to the normative component. However, both the descriptive component, "I see myself as quiet, as a shy person, but when I'm in my classroom, that's where I perform", and the normative component, "It doesn't matter what qualifications I've got, we are here at the end of the day because of the children", seem intact. She links the normative component to her didactical competence and its value for the learners, "For me at the end of the day, if my children fare well, I'm good", rather than attainment of higher qualifications. The evaluative component, which depends on indicators such as comparison with other teachers and the learner performance also seem intact, " $a$ lot of people will tell you that they compete [...] but for me that's not important". It seems that only the conative component of P2's professional self or identity was affected, "when your colleagues work against you; that is very demotivating" and "people who think they know more than you, who are not prepared to learn from you, and then you just feel, sometimes you just feel it's not worth it" (P2; 3rd interview). Further analysis of P2's autobiographical narratives shows that, like P1 above, she has learnt to counterbalance the effects of negative circles of recognition with the effects of positive circles of recognition drawn from experiences elsewhere. She has two stories of experiences that involve intersubjective recognition and that show all of the characteristics of positive circles of recognition in her narrative repertoire. The first story relates to Honneth's (1995) first level of recognition, the establishment of self-confidence, and primary relations of love and care in her family.

The support system was there; you know what I'm saying? My parents were there, but I could never go to them, and ask them to help me with homework. I had to do it on my own. I've got a brother and a sister who are younger than me. We had to sit and figure out things for ourselves. Even at high school when homework... they wouldn't ask if you'd done your homework. You must just know that you must do your homework. So, I knew they were there, but they couldn't support as far as content [...] They were not educated; you know what I'm saying? My father, well, he must have done Standard 6, my mother didn't even finish primary school. So, that is the way they couldn't support us, but in every other way, we knew that we could depend upon them. They supplied... the things, it was there. My father was the only one who worked. My mother never worked. She was a housewife which was a plus point because in the afternoon you come home, she is at home. So that was a plus point. 
She may not have been able to help me academically, but the fact that she was there, made a big difference. We knew that we could depend upon them. If I asked for anything then we would be told: we cannot afford it at this time, but we will get it for you sometime. So, that was a good thing. What else? But like I say, academically, and when it came to anything school, you had to fight it through on your own (P2, 2nd interview).

The effects of positive circles of recognition are evident in the reciprocal recognition between parents and children, "they couldn't support us [with homework], but in every other way, we knew that we could depend upon them", and, "they wouldn't ask if you'd done your homework. You must just know that you must do your homework"; and, in the solidarity among them, "the fact that she [their mother] was there, made a big difference. We knew that we could depend upon them". The love and care necessary for the development of self-confidence was there, "The support system was there [...] My parents were there”. She knew that she could express her needs freely without fear of rejection or abandonment, "we knew that we could depend upon them. They supplied... the things, it was there". Her self-confidence was further strengthened, because their parents could not help with their schoolwork so the children had to help themselves, "when it came to anything school, you had to fight it through on your own". This was useful because in made her confident in her own abilities. The second story is about her experiences of participating in the regional cluster system. These are professional communities of practice, in discipline specific areas, that involve teachers from different schools in a geographic region.

Ever since we [teachers] have started the clusters where we work together in groups, just like the schools in the Northern Areas [of Port Elizabeth] it's... been very, what is the word? Motivating! Because we get together and discuss problems we may have, we get together and we work on question papers together... This week or next week again we're going to have our meeting [...] It works, uhm, like a bomb! [...] each school gets a turn to set papers. And then, not only get together for papers, we get together to discuss how we can help one another... What am I doing that's working, and how can we assist one another, and then, also friendships have been cemented even through this (P2; 1st interview)

The effects of positive circles of recognition are evident in the reciprocal recognition and solidarity amongst cluster members, "we get together and discuss problems we may have, we get together and we work on question papers together [...] we get together to discuss how we can help one another... What am I doing that's working, and how can we assist one another [...] friendships have been cemented"; and job satisfaction, "It works, uhm, like a bomb!" The obvious differences between her experiences of intersubjective recognition as a member and participant in the cluster system and the lack of respect and disrespect of her colleagues at school prompted this reflection: "People in the clusters don't know you as good as the people on your staff. You don't work every day with people in the cluster. So, I don't know if the problem is with me, or what. Many times I have asked myself the question. Am I the problem? What am I doing wrong?" (P2; 2nd interview). Nevertheless, the intersubjective recognition received within the cluster system compensates for denied intersubjective recognition of her colleagues at school, "[M]aybe the cluster makes up for it because we work extensively together. We're at the stage now where we email tasks and tests and exam papers to one another, so maybe that makes up for it. But 
it's still not the same as having somebody here at the school" (P2; 3rd interview). Her experiences in the cluster system, "Motivating! Because we get together and discuss problems we may have [...] It works, like a bomb! [...] we get together to discuss how we can help one another", help to counteract the demotivating experience with her colleagues at school, “you've tried, you've tried to speak, you've tried to sort it out [...] but the person is just not giving his cooperation, what more can you do?" To summarise, P2 has been able to remain resolute in maintaining of her self-respect amidst the continuous struggle against the disrespect shown by her colleagues, because she has learnt how to counterbalance the effects of negative circles of recognition with the effects of positive circles of recognition drawn from experiences beyond the immediate context of her struggles.

\section{The Story of Participant 3}

In this story, Participant $3(\mathrm{P} 3)$ recounts the struggle for recognition of his worth as a mathematics teacher in a context of affirmative action where his hard work and dedication over the years were not recognised and rewarded. This happened at a school in a historically White neighbourhood of Port Elizabeth where P3 had started his teaching career at least thirty-two years before the interview. In the context of the post-apartheid schooling system, the demographic profile of staff and learners has shifted from exclusively White to almost exclusively Non-white.

And then I started applying for deputy head posts, etcetera, because I felt I was ready for that $[\ldots]$ Unfortunately, for me there was a lot of turmoil in the education area and a lot of re-deployments, if you can remember. And, people were redeployed from certain other schools, and came to our school, and were brand new in our situation [...] and their promotion was given above mine. In other words, they were promoted to a deputy [...] my service and loyalty and dedication and passion counted for zippo at that particular stage [...] This used to be traditionally a White school and there were White teachers... that people of colour were given the opportunity [...] That was the hardest time, the disappointment of not being recognised despite all the work that I was putting in $[\ldots]$ and it knocked my passion a little bit in terms of the school. Not in terms of the maths, but in terms of the school itself... It was a bit of a setback [...] That was one incident, and, and the biggest one by far because since then I haven't actually wanted to apply. There have been situations where I could have applied again, but I haven't wanted to. I just feel that I don't, I don't want that anymore. It's sort of being ripped out of my heart, that part (P3, 1st interview).

The disrespect shown in this story is typical of Honneth's (1995) third level and is about and the struggle for self-esteem and for P3's worth as a teacher to be recognised. The story is about the denigration and insult of not getting the desired promotion post, regardless of all the hard work and the extra responsibilities that he had taken on: "my service and loyalty and dedication and passion counted for zippo at that particular stage". The school had to apply affirmative action and P3 was overlooked for the promotion post. The effects of negative circles of recognition are evident in a lack of solidarity and diminished motivation for teamwork, "it knocked my passion a little bit in terms of the school. Not in terms of the maths, but in terms of the school itself"; and, in the emotional reactions of P3 to the perceived disrespect, "since then I haven't actually wanted to apply. There have been situations where I could have applied again, but I haven't wanted to. I just feel that I don't, I don't 
want that anymore. It's sort of being ripped out of my heart". The denial of P3's promotion probably had less to do with disrespect and misrecognition of hard work and dedication and more to do with the politics of transformation and affirmative action; for instance, there is no evidence of persons downplaying each other typical of negative circles of recognition. From a narrative perspective, however, it is more important to know how P3 makes sense of this experience; and, he made the negative effects on his self-esteem as a teacher and as a father quite clear.

[W] hen that disappointment of that promotion thing happened, I actually felt, not only disappointed [...], but I felt almost like I'd let my family down in terms of I told them that hard work and dedication and being on time was so important and that you will be rewarded for that. And here I was, having done all of that, and not getting rewarded. So it was almost like I'd said the wrong thing to my children. I know I didn't, but it was... They looked at me and thought, 'Gosh, I wonder if this old man's been telling the truth all the time?' So it was more of a personal thing at home as well. It was like a disappointment. I felt that I'd let down my family (P3, 3rd interview).

A prerequisite for recognition on Honneth's (1995) third level is an intersubjectively shared orientation to common values and goals, "that indicate to each other the significance or contribution of their qualities for the life of the other" (p. 121), which usually culminates in enhanced self-esteem of the recognised. In P3's story, such intersubjective solidarity is missing. His struggle is the result of a mismatch between his personal goal of promotion, perceived as a form of recognition for "hard work dedication" which is linked to his personal values of "service and loyalty and dedication and passion" and the institutional goal of transformation by promoting people of colour through affirmative action "people of colour were given the opportunity". This experience has affected P3's self-esteem as a father and family man; calling into question the integrity of the values he had taught to his children and amplifying the effects of the negative circle of recognition; and the evaluative and conative components (Kelchtermans, 1993) of his professional self or identity. This is evident in the emotional comments, "[T] hat was the hardest time, the disappointment of not being recognised despite all the work that I was putting in", which indicates that he had used his application for promotion as a crude evaluation of his worth as a teacher; and 'I just feel that I don't, I don't want that anymore. It's sort of being ripped out of my heart", which indicates how demotivating the experience has been. Having one's ego-claims disregarded can be so emotionally overwhelming that one becomes incapable of continuing with an action (Honneth, 1995). This seems to be the case with P3 not wanting to apply for promotion anymore. While some of his previous colleagues left the school because of similar experiences, "People that were here didn't really count for much. Some of the newcomers got in... You know! [...] People did leave" (P3; 1st interview), P3 has learnt to survive by counterbalancing the effects of negative circles of recognition with the effects of positive circles of recognition drawn from other life experiences. Two positive stories in his narrative repertoire, both linked to Honneth's (1995) first level of recognition, emotional bonding (love), stand out. The first one is about self-confidence gained through the love and care in his family life. 
I want to start with my own family life [...] My family was a very normal... sort of united family [...] My Mum was always at home! That was very important. I remember when I, when I got home from school, my mother was at home [...] Those issues one doesn't realise as a child, when you're growing up, have a huge supporting role because the parent is showing such an interest in you, you then feel obliged to show an interest in your schoolwork! [...] My father was always there from a sporting point of view [...] He'd ask me about my Maths but worked late hours so he could not really help. So, none of them helped me physically with the actual doing of the Maths, but they helped me with the motivation of it [...] They'd sacrifice some of their own things so that we could get on in life [...] That inward motivation to succeed, that is something that I think one gets if you, I don't know if this is true or not, but I feel that if you come from a slightly deprived background or poorish background, there's definitely this will to get to improve your own life, so that your family's life can improve (P3; 2nd interview).

A "very normal... sort of united family" life has enabled P3 to establish selfconfidence, knowing that he could depend on the love and care of his parents and that his needs could be expressed without fear of rejection or abandonment because "[t]hey'd sacrifice some of their own things so that we could get on in life". His mother was "always at home" and ready to make sure that all of his needs were taken care of and his father also tried to do his part, but he was mostly at work, "he'd ask me about my Maths but worked late hours so he could not really help", so he focussed on the sport. Their actions can be linked to Honneth's (1995) first level of recognition where such emotional bonding (love) is necessary for the attainment of self-confidence. The effects of positive circles of recognition are evident in the reciprocal recognition between parent and child and feelings of solidarity and mutual satisfaction, "because the parent is showing such an interest in you, you then feel obliged to show an interest in your schoolwork, which in fact is what your parents are wanting you to do!" The attainment of self-confidence has laid the foundations for the attainment of his degree and self-respect knowing that he has earned the legal right to practice as a professional mathematics teacher. There is only evidence of Kelchtermans' (1993) conative component a professional self in this story. P3 refers to it his "inward motivation to succeed" in his job which stems from having witnessed how his parents (particularly his father) struggled: "You know, so I think the inward motivation comes from trying to live a better life than maybe my parents had lived"(P3; 2nd interview). This resilience, together with a firm and resolute self-confidence, all effects of the positive circles of recognitiMarkkuon evident in this story, are the counterbalances that help him to neutralise the effects of negative circles of recognition such as those evident in the story of the denied promotion post. Other stories of P3 that involve positive circles of recognition are mostly anecdotal and about previous learners, for instance, the following one of a chance encounter with a previous learner in a supermarket:

It's made me understand [...] what a big effect that you have on children's lives. As you teach children from grade eight to grade twelve, you teach them mathematics, and you forget that you are teaching them life skills and that you are a role model for them... serving as a role model. You forget about those things... those things however come back to you when you bump into a child, which I still do, uhm, in a supermarket and he says he'll never forget the time... that he got disciplined by me for not doing his homework. He then did his homework and he passed maths and today he's financially secure with a sound job, and he, he'll show 
genuine appreciation. So that has changed my... It hasn't changed me, but it has made me aware of the impact that you have on children's lives, other than just mathematics (P3; 1st interview).

This is another example of recognition linked to Honneth's (1995) third level, a shared orientation to values (solidarity), which strengthens of P3's self-esteem. The effects of positive circles of recognition (Huttunen \& Heikkinen, 2004a, 2004b) are evident in the reciprocal recognition between the previous learner and $\mathrm{P} 3$, with the learner showing "genuine appreciation" for the role that P3 has played in his life and with P3 recognising the learner for making him "aware of the impact that you [P3] have on children's lives, other than just mathematics", but also in the mutual feelings of solidarity and satisfaction with the outcome of the disciplinary action taken by P3 against the previous learner, with the learner turning out "financially secure with a sound job" and showing "genuine appreciation". This experience has prompted P3 to reflect on two components of Kelchtermans' (1993) professional self. The evaluative component because of the of "big effect that you have on children's lives", is construed as positive for his self-esteem; and, the normative component, "you teach them mathematics, and you forget that you are teaching them life skills and that you are [...] serving as a role model" extended the mathematics teacher's job to include life-skills and role modelling.

These are the narratives of the participants' struggles for professional recognition; the strategies that they have developed to cope with it; and, how these have affected their professional identities.

In conclusion, while the sample in this study is far too small to yield any generalizable results, it does highlight a few pertinent issues related to the struggle for recognition and the professional identities of mathematics teachers. For instance, the sample included participants representative of the socio-cultural spectrum of mathematics teachers across government-funded schools in the Eastern Cape Province of South Africa, yet there was very little variation in their nature of their stories. Perhaps, because the focus was on teachers who had managed to survive the on-going and sometimes radical changes in the post-apartheid education system, and therefore there would be similarities in their experiences and survival strategies. One similarity is that all of them have a strong sense of self-confidence grounded in narratives of loving and caring family relations; they know who they are and they are able to draw on this in the their struggles for recognition. Another is that all of the participants are qualified mathematics teachers, which gives them the self-respect to practice as professionals with the necessary legal and moral authority; they know what they are and are able to draw on this in their struggles for recognition. The only apparent anomaly is the second participant (P2) whose struggle appeared to be for self-respect, even though she is a qualified mathematics teacher. She struggles, not because she has no self-respect, but because her self-respect is threatened. Her struggle is for maintenance of her self-respect. Another striking similarity amongst the participants is that their struggles for recognition are at the level of self-esteem; that is, for recognition of their worth as mathematics teachers. Another pertinent similarity is that participants seem to have developed an ability to cope with their struggles for recognition by 
counterbalancing the effects of negative circles of recognition on their professional identities with the effects of positive circles of recognition drawn from other experiences beyond the immediate contexts of their struggles. To enhance the significance of this finding, it should be corroborated in different contexts. Perhaps, if more is known about this is a coping strategy, it could be used to assist other teachers so that less of them will be inclined to give up the struggle for recognition and leave the profession. This study introduced a novel set of theoretical lenses consisting of Honneth's (1995) three hierarchical levels of recognition; Kelchtermans' (1993) four components of a professional self; and, Huttunen and Heikkinen's (2004a) circles of recognition; and, demonstrated how these theoretical lenses could be used to make sense of narratives of recognition and professional identities. Finally, recognition lies at the heart of education and yet many worthy teachers do not receive the recognition that they deserve and many leave the profession. More research is necessary to get a better understanding of recognition in education. Perhaps the pertinent issues highlighted in this study should be studied in more detail, perhaps in different contexts, to render a more holistic picture and data that could be generalized across contexts.

\section{References}

Anspal, T., Eisenschmidt, E., \& Löfström, E. (2012). Finding myself as a teacher: Exploring the shaping of teacher identities through student teachers' narratives. Teachers and Teaching: Theory and Practice, 18(2), 197-216.

Caruso, L. F. (2013). The micropolitics of educational change experienced by novice public middle school principals. NASSP Bulletin, 97(3), 218-252.

Castañeda, J. A. (2014). Learning to teach and professional identity: Images of personal and professional recognition. Profile, 16(2), 49-65.

Clandinin, D. J., \& Connelly, F. M. (2000). Narrative inquiry: Experience and story in qualitative research. San Francisco, CA: Jossey-Bass.

Connelly, F. M., \& Clandinin, D. J. (1990). Stories of experience and narrative inquiry. Educational Researcher, 19(5), 2-14.

Creswell, J. W., \& Miller, D. L. (2000). Determining validity in qualitative inquiry. Theory into Practice, 39(3), 124-130.

Daiute, C., \& Lightfoot, C. (2004). Theory and craft in narrative inquiry: Editors' introduction. In C. Daiute \& C. Lightfoot (Eds.), Narrative analysis: Studying the development of individuals in society (pp. vii-xviii). Thousand Oaks, CA: Sage.

Fleming, T., \& Finnegan, F. (2010). Honneth and recognition as sensitizing concept for narrative analysis: An Irish suggestion. Retrieved from http://www.dsw.edu.pl/fileadmin/www-ranlhe/ files/Honneth_and_Recognition.pdf.

Glaser, B. G., \& Strauss, A. L. (1967). The discovery of grounded theory: Strategies for qualitative research. Chicago, IL: Aldine.

Guba, E. G. (1981). Annual review paper: Criteria for assessing the trustworthiness of naturalistic inquiries. Educational Communication and Technology, 29(2), 75-91.

Heikkinen, H. L. (2003). Becoming a teacher-Struggling for recognition. Paper presented at the European Conference on Educational Research, University of Hamburg, September 17-20, 2003. Retrieved from http://www.leeds.ac.uk/educol/documents/00003446.htm.

Honneth, A. (1995). The struggle for recognition: The moral grammar of social conflicts. (J. Anderson, Trans.). Cambridge, UK: Polity Press. 
Honneth, A. (2012). The I in we: Studies in the theory of recognition (English ed.). (J. Ganahl, Trans.) Cambridge, UK: Polity Press.

Huttunen, R. (2001). Critical adult education and the political-philosophical debate between Nancy Fraser and Axel Honneth. Educational Theory, 57(4), 423-433.

Huttunen, R., \& Heikkinen, H. L. (2004a). Teaching and the dialectic of recognition. Pedagogy, Culture \& Society, 12(2), 163-174.

Huttunen, R., \& Heikkinen, H. L. (2004b). Recognise me, respect me! Retrieved from http://www. oulu.fi/ktkold/life/Julkaisut/tekstit/ecer.htm.

Ikäheimo, H. (2002). On the genus and species of recognition. Inquiry, 45(4), 447-462.

Kelchtermans, G. (1993). Getting the story, understanding the lives: From career stories to teachers' professional development. Teaching and Teacher Education, 9(5/6), 443-456.

Kelchtermans, G. (2004). CPD for professional renewal: Moving beyond knowledge for practice. In C. Day \& J. Sachs (Eds.), International handbook on the continuing professional development of teachers (pp. 217-237). Buckingham: Open University Press.

Kramp, M. K. (2004). Exploring life and experience through narrative inquiry. In K. deMarrais \& S. D. Lapan (Eds.), Foundations for research: Methods of inquiry in education and the social sciences (pp. 103-121). Mahwah, NJ: Lawrence Erlbaum.

Miles, M. B., \& Huberman, A. M. (1994). Qualitative data analysis (2nd ed.). Thousand Oaks, CA: Sage.

Murphy, M. (2010). On recognition and respect: Honneth, intersubjectivity and education. Educational Futures, 2(2), 3-11.

Schaap, A. (2004). Political reconciliation through a struggle for recognition. Social \& Legal Studies, 13(4), 523-540.

Scholes, B., \& de González, G. (2011). The nature of recognition in TEFL teachers' lives. Profile, 13(1), 75-87.

Taylor, C. (1992). The politics of recognition. In C. Taylor \& A. Gutmann (Eds.), Multi-culturalism and "the politics of recognition" (pp. 25-73). Princeton, NJ: Princeton University Press.

Vanassche, E., \& Kelchtermans, G. (2016). A narrative analysis of a teacher educator's professional learning journey. European Journal of Teacher Education, 1-13.

Vandenberghe, R. (1996). The staff room: A key place to understand professional culture. Teaching and Teacher Education, 12(1), 115-117.

Open Access This chapter is licensed under the terms of the Creative Commons Attribution 4.0 International License (http://creativecommons.org/licenses/by/4.0/), which permits use, sharing, adaptation, distribution and reproduction in any medium or format, as long as you give appropriate credit to the original author(s) and the source, provide a link to the Creative Commons license and indicate if changes were made.

The images or other third party material in this chapter are included in the chapter's Creative Commons license, unless indicated otherwise in a credit line to the material. If material is not included in the chapter's Creative Commons license and your intended use is not permitted by statutory regulation or exceeds the permitted use, you will need to obtain permission directly from the copyright holder.

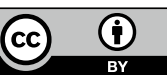

